\title{
DIE OPLEIDING VAN BEDRYFSIELKUNDIGES \\ AAN DIE UNIVERSITEIT VAN PORT ELIZABETH
}

\section{KAMFER}

\section{DEPARTEMENT BEDRYFS- EN ORGANISASIESIELKUNDE UNIVERSITEIT VAN PORT ELIZABETH}

U.P.E. het in 1965 met die opleiding van studente begin. Gedurende 1966 is die Departement Bedryfsielkunde as volwaardige departement in die Fakulteit Ekonomiese Wetenskappe ingestel, nadat die Departement Sielkunde in 1965 die eerste inleidende kursus in die bedryfsielkunde aangebied het.

Gedurende 1975 is die naam van die departement verander na die Departement Bedryfen Organisasiesielkunde. Dit is gedoen omdat essensiële ontwikkelings en klemverskuiwinge wat in die bedryfsielkunde plaasgevind het, in die bedryfsielkundeleerplanne by U.P.E. gereflekteer word.

\section{Personeel}

Die departement bestaan uit 'n professor, senior lektor, lektrise en 'n heeltydse navorsingsassistente. Baie waarde word aan praktiese ervaring en volgehoue kontak met die praktyk geheg. Drie van die dosente het voor hul aanstelling by U.P.E. uitgebreide navorsings- en praktiese ervaring in die bedryf gehad, en is steeds in 'n konsulterende verband met die praktyk in aanraking.

Die departement glo ook in gereelde oorsese besoek. Die drie senior lede het aldrie uitgebreide oorsese ondervinding. Een was tweekeer ook besoekende professor in die V.S.A.

\section{Studentegetalle}

Vir 1977 is studentegetalle soos volg:

$\begin{array}{lr}\text { Eerstejaars: } & 64 \\ \text { Tweedejaars: } & 35 \\ \text { Derdejaars: } & 22 \\ \text { Honneurs: } & 11 \\ \text { Meestersgraad: } & 4\end{array}$


Tot dusver is die volgende getalle nagraadse kwalifikasies verwerf:

$\begin{array}{lr}\text { Honneursgrade: } & 27 \\ \text { Meestersgrade: } & 15 \\ \text { Doktorsgrade: } & 2\end{array}$

\section{Aanbieding}

Die tuisfakulteit vir Bedryf- en Organisasiesielkunde is die Fakulteit Ekonomiese Wetenskappe. B.Com.-studente kan dus die vak as hoofvak neem. Dit word ook vir die Fakulteit Lettere en Wysbegeerte aangebied, sodat B.A.-studente ook Bedryf- en Organisasiesielkunde as hoofvak kan neem en nagraads daarmee kan voortgaan.

Studente uit die Bouwetenskappe en uit die Verpleegkunde woon dienskursusse in die vak by.

Voorgraadse lesings word na-uurs herhaal sodat ook deeltydse B.Com.- en B.A.studente Bedryf- en Organisasiesielkunde kan neem.

Die eerstejaarskursus word in Engels aangebied, die tweede jaar in Afrikaans en Engels, en een kursus in die derde jaar ook in Engels, met die orige drie in Afrikaans.

\section{Benadering tot die vak}

\section{Algemeen}

Verskeie aannames word ten opsigte van die vak gemaak:

- $\quad$ Studente moet breed opgelei word, in die sin dat hulle 'n goeie agtergrond in die Algemene Sielkunde asook die Sosiale Sielkunde moet besit. Ons is eers sielkundiges, daarna bedryfsielkundiges.

- $\quad$ Bedryf- en Organisasiesielkunde het 'n sterk praktiese en toegepaste geaardheid. Metodes en tegnieke in die vak word dus, ook op voorgraadse basis, beklemtoon.

- $\quad$ Skakeling en konsultasie met die bedryf is belangrik. Sulke kontak word aangemoedig. Praktiese ervaring word in die klasse teruggeploeg. Ook kom waardevolle navorsingsgeleenthede sodoende tot stand, sodat dosente, studente en hopelik die kliëntorganisasies deur sodanige interaksies bevoordeel word. 
- $\quad$ Die departement erken die belangrikheid van navorsing en hou 'n aktiewe navorsingsprogram in stand.

- $\quad$ Bewuste aandag word aan didaktiese metodes gegee en 'n groot verskeidenheid doseerbenaderings word gebruik. Hierdie sluit in praktiese werk, gevallestudies, rolspel, kleingroep-toepassings en eksperiënsiële metodes.

- $\quad$ Die departement is nog jonk en klein. Hierdie eienskappe word as bates beskou en as sulks benut. Persoonlike kontak met studente is moontlik. Waar toepaslik werk personeel en studente as 'n span saam.

- Die professionalisme van die bedryfsielkundige en die beskerming van die vak wat deur Wet Nr. 56 van 1974 soos gewysig deur Wet Nr. 33 van 1976 verskaf word, word as belangrike bates beskou. Kursusinhoude word só beplan dat kriteria wat deur die Beroepsraad vir Sielkunde van die Suid-Afrikaanse Geneeskundige en Tandheelkundige Raad gestel mag word, bevredig sal kan word, sodat studente na die vereiste praktiese ervaring as psigotegnici of as sielkundiges sal kan registreer.

Kursusse

Eerste jaar - Eerste semester: Introduction to General Psychology

Practical work

Tweede semester: Introduction to Psychology continued

Practical work (continued)

Introduction to Industrial and Organizational

Psychology

Tweede jaar - Eerste semester: Personeelsielkunde

Prakties - personeeltegnieke

Introduction to Social Psychology

Tweede semester: Personeelsielkunde (vervolg)

Psychopathology

Practical - personnel testing

Derde jaar - Eerste semester: Group Dynamics

Inleiding tot die Verbruikersielkunde

Prakties-Groepsdinamika en Verbruikersielkunde

Tweede semester: Inleiding tot die Organisasiesielkunde

Psigopatologie en Geesteshigiëne van die Bedryf 
Honneurs: Gevorderde Organisasiesielkunde

Gevorderde Verbruikersielkunde

Gevorderde Personeelsielkunde en Nywerheidsverhoudings

Navorsingsmetodiek

Een keuse-vraestel uit die volgende: Algemene Sielkunde, Sosiale Sielkunde,

Bedryfsosiologie of Bedryfsekonomie

Suid-Afrikaanse Arbeidsreg (Bywoningskursus)

Praktiese werk, insluitende gevorderde personeeltoetsing

\section{Voorvereistes en kombinasiemoontlikhede}

Die departement voel sterk dat die waarde van studie in die Bedryf- en Organisasiesielkunde grootliks verhoog kan word deur dit binne 'n relevante raamwerk aan te bied.

Eerstens moet alle studente wat Bedryf- en Organisasiesielkunde as hoofvak wil neem, die volgende voorvereiste vakke in hul leergang insluit:

- $\quad$ Ekonomiese Geskiedenis (Bywoningskursus)

- $\quad$ 'n Inleiding tot Elektroniese Dataverwerking. (Bywoningskursus)

- $\quad$ 'n Inleiding tot Suid-Afrikaanse Industriële reg. (Bywoningskursus)

- $\quad$ Statistiek (Eksamenkursus)

Daarbenewens mag B.A.-studente 'n vak uit die Ekonomiese Wetenskappe kies (bv. Bedryfsekonomie I), terwyl B.Com.-studente toegelaat word om sekere gedragswetenskaplike vakke uit die Fakulteit Lettere en Wysbegeerte te kies soos byvoorbeeld Volkekunde I en II, gedeeltes van Maatskaplike Werk en Sosiologie en Xhosa I.

Wat die keuse van 'n tweede hoofvak betref kan B.A.-studente o.a. een van die volgende met Bedryf- en Organisasiesielkunde III kombineer: Sosiologie III, Ekonomie III, Wiskundige Statistiek III, Publieke Administrasie III, Volkekunde III, Geografie III, Wiskunde III, Staats leer III, Rekenaarwetenskap III.

B.Com.-studente kan een van Bedryfsekonomie III, Wiskunde III, Wiskundige Statistiek III, Ekonomie III, Rekeningkunde III, Ondernemingsnavorsing III saam met Bedryf- en Organisasiesielkunde III as hoofvakke neem. 
Terwyl daar gepoog word om die vak 'n breë, kontemporêre, organisasiebasis te gee, word veral op die Personeelsielkunde en die Verbruikersielkunde klem gelê. Binne die Personeelsielkunde ontvang Motivering, Loon- en Salarisadministrasie, en Nywerheidsverhoudinge besondere klem op nagraadse vlak. In die Verbruikersielkunde geniet sielkundige aspekte, invloede en prosesse by verbruikersbesluitneming veral die aandag. Die belangrikheid van 'n navorsingsoriëntasie word beklemtoon.

\section{Doseermetodes}

'n Aanname wat ten opsigte van studente gemaak word, is dat hulle so gou moontlik gelei moet word om onafhanklik te studeer.

Dosente maak van gepaste doseertegnieke gebruik, bv. projekwerk, seminaarwerk, gevallestudies, eksperiënsiële metodes.

\section{Navorsing}

Wat Personeelsielkunde betref is daar a1 geruime tyd 'n sterk navorsingsoriëntering in die Departement. Projekte is reeds sedert 1972 deur die RGN en ander instansies soos die WNNR en die bedryf gesteun. Op die oomblik beskik die departemente oor 'n drie-jaar RGN "groter toekenning". Die departement se personeelnavorsing het begin met die ontwikkeling van statistiese maatstawwe om arbeidsomset en afwesigheid in bedryfsorganisasies te versyfer en te evalueer. 'n Groot sektor van die plaaslike nywerheid is steeds hierby betrokke, maar in on1angse jare is oorgegaan na 'n baie breër ontleding binne uitgesoekte organisasies van daardie faktore wat onderskei tussen organisasies met stabiele en onstabiele werknemers. Onder die breë doelstelling van organisasie-effektiwiteit word tans studies uitgevoer op struktuur, leierskap, besoldiging, bestuurskommunikasie en -verwagtinge binne organisasies. Studente en dosente werk saam, en daar is 'n klem op praktiese ondersoek binne die organisasies, wat waardevolle ondervinding aan studente verskaf.

In die veld van die Verbruikersielkunde word sedert 1970 ondersoeke na die koopgedrag van motoreienaars binne die Suid-Afrikaanse motorhandel gedoen. Die doel van die ondersoeke is 'n ontleding van die objektiewe koopsituasie en 'n bepaling van kooppatrone ten opsigte van motoraankope by verskillende 1eeftydsgroepe. Vraelyste en persoonlike onderhoude is veral gebruik om data in te samel. Navorsing word ook onderneem ten opsigte van die Swart verbruiker se beeld van 'n motor. In hierdie ondersoek word hoofsaak1ik van projeksietegnieke gebruik gemaak. 


\section{Beroepsaspekte}

Oud-studente van U.P.E. wat Bedryf- en Organisasiesielkunde as hoofvak of nagraads geneem het, beklee tans 'n groot verskeidenheid van poste dwarsoor die land, in personeel, bemarking, algemene bestuur, of ander rigtings waar hulle gedragswetenksaplike opleiding hulle in staat stel om beter werkers en bestuurders te wees.

Die Departement Bedryf- en Organisasiesielkunde beklemtoon deurgaans by sy studente die belangrikheid van doelwitbereiking vir organisasies, en beklemtoon die primêre en sekondêre bydraes wat gedragswetenskaplikes in organisasies hiertoe kan lewer. 